\title{
Cultivating an Entrepreneurial Mindset
}

SANDRA A. MATHESON, MSc,RD, FDC, Food Systems Consulting Inc., Oakville, ON

\begin{abstract}
Now as never before, familiar challenges require bold, novel approaches. Registered dietitians will benefit by cultivating an entrepreneurial mindset that involves being comfortable with uncertainty, learning to take calculated risks, and daring to just try it. An entrepreneur is someone who takes risks to create something new, usually in business. But the entrepreneurial mindset is available to anyone prepared to rely only on their own abilities for their economic security and expect no opportunity without first creating value for others.
\end{abstract}

(Can J Diet Pract Res. 2013;74:146-149)

(DOI: 10.3148/74.3.2013.146)

\section{RÉSUMÉ}

\begin{abstract}
Maintenant comme jamais auparavant, les défis courants requièrent des approches audacieuses et novatrices. Les diététistes gagneront à cultiver un esprit d'entrepreneuriat, qui suppose être à l'aise avec l'incertitude, apprendre à prendre des risques calculés et oser essayer. Un entrepreneur est une personne qui prend des risques afin de créer quelque chose de nouveau, généralement dans le secteur des affaires. Toutefois, l'esprit d'entrepreneuriat est accessible à toute personne prête à se fier à ses propres capacités pour assurer sa sécurité financière et à ne pas s'attendre à obtenir du rendement sans d'abord créer de la valeur pour les autres.
\end{abstract}

(Rev can prat rech diétét. 2013;74:146-149)

(DOI: $10.3148 / 74.3 .2013 .146)$

\section{INTRODUCTION}

If you could do what you want to do, what would you do? Would it be different from what you are doing now? What prevents you from making any needed changes? In a recent presentation in Hamilton, Ontario, Oprah Winfrey opened her show with "Turn up the volume on your life". She followed that by saying "I'm here tonight in Hamilton because I want to be. I no longer do anything I don't want to do." How many of us could say the same thing?

Today I urge you to adopt an entrepreneurial mindset. I will review some of the things I have done as an entrepreneur to give you a bit more comfort that what I am suggesting might not be as much of a reach as you might think at first. I also want to provoke you into becoming more of a risk taker; being prepared to put yourself out there, to turn up the volume on your life. It is about making a decision to move in a particular direction and then 'just doing it". No elaborate plan, objectives, tasks, to do lists....just doing whatever it takes every day.

\section{My Career}

Over 28 years ago, I left the security of a salaried position to start a business and I have never looked back. Yes, there was less competition; yes, it was a less complicated world, but we didn't have the kind of digital productivity tools now available, nor access to the internet and there was not the broad based interest in health and well-being. There is no better time than now to become an entrepreneur.
My success formula:

1. Being well prepared

2. Having an international network of colleagues

3. Being a self-directed learner

4. Creating businesses that are sustainable

5. A key relationship

\section{Being Well Prepared}

My mother was widowed at age 28 with five children under age six. Her strength, organizational skills and positive outlook were great gifts to all of us, as were the support and lasting friendship of the people in that small Miramichi community. When at an early age you are the recipient of many kindnesses, it makes you appreciate how being of service to others matters; to them and to you. I remember feeling very fortunate despite a few economic challenges. It may be the reason that I am fundamentally optimistic, so taking risks doesn't scare me.

From those Maritime roots, my love of food and cooking carried on as I took the technical Home Economics program in High School. This prepared me to be successful in gaining a bachelor degree in Foods and Nutrition from Mount Allison University and then a Master's of Science degree in Nutrition from the University of Toronto. Along the way, I spent the summers with the Royal Canadian Air Force in their reserve officer training program. Much later than Violet Riley and Kathleen Jeffs, I was exposed to the role of a Foodservices Officer in the 
armed forces and developed a great deal of respect for the senior female officers who had to learn to hold their own in a very male-dominated world.

After graduate school, I returned to New Brunswick to a job waiting for me as the Provincial Nutritionist. We undertook a major project with the Department of Education to determine how to create cafeterias in the schools so fresh foods could be served instead of shelf-stable confectionery and potato chips. With the help of Bernard and Associates (B\&A) of Montreal, we developed layouts and equipment budgets to encourage school boards to include cafeterias in their school building projects. In one very revealing conversation with Ron Newton, the Regional Manager of Beaver Foods (later Compass Canada) he said to me, "Sandra, you just don't understand. We need to sell French fries to be able to provide milk and other nourishing items. You don't understand how a foodservices business works". This was why I turned to foodservices. I needed to understand this. I didn't want to be some Pollyanna filled with pie-eyed ideas; I wanted to learn how to run a successful business offering good, fresh, healthy food.

I next took a position in London, Ontario with Beaver Foods, Ltd. as their Corporate Nutritionist. We created a K-12 school nutrition awareness program, Four Plus; a college program, The Good Life, and a program for business and industry accounts, Healthier Eating. This kind of extensive nutrition education and awareness program from a private sector contractor was unheard of at that time. Today, although the school food and nutrition policy in Ontario is a bit over the top in its specifications, it is a high water mark in terms of an achievement regarding food sold in schools. Kudos to the registered dietitians (RDs) and others who made that happen. The challenge remains to make it work as a business.

Then an opportunity arose to join B\&A as their vice-president for Ontario. The variety of work and projects was enormous and the learning curve straight up. One great opportunity was to work with the Arthur Erickson team first on Roy Thomson Hall in Toronto and then on the design of the new Canadian Embassy in Washington.

With B\&A I did have bottom-line responsibility for our office. Trudi Bernard is a true pioneer in our profession, one of the few dietitians to specialize in planning and to build a consulting practice that still operates today. Claudette Corneillier is an exceptional foodservice management specialist. It was an education to work for them; I learned so much, not just about foodservices facilities and operations but also about being a consultant and managing a consulting business.

Consulting is a specialized field in itself. Being a good consultant is different from being a good operator; it requires a different yet learnable skill set. As in any business, it requires being a people person, meaning you enjoy people of very different personalities and can work with almost anyone. Successfully managing relationships is key.

\section{International Network}

Along the way I met many 'Home Ec'ers', dietitians and nutri- tionists who have become trusted friends and allies. Bev Musten and Doryne Peace started Peace and Musten right out of our grad school experience and both went on in the private sector. Others were Marilyn Knox, Mary Bush, my many Ontario and Canadian Dietetic Association friends on the Board and in committee work, and Ellyn Luros, former President of Computrition and a great ally for connections in the U.S.A. I must also pay tribute to one of the most extraordinary $\mathrm{RD}$ entrepreneurs we have had: Eleanor Brownridge was a good friend and colleague since we met in London, Ontario, in 1978. Eleanor was not afraid to take risks and put herself and her talent out there; whether in her writing or glass work. She led a full and productive life contributing in so many ways. Eleanor passed away in the spring of 2013 and will be sadly missed.

\section{Sustainable Businesses}

Starting my own consulting business in 1988 was a calculated risk. I was well prepared, had the experience and network, had a certain profile, and had an RRSP that I could dip into if necessary. Success happens when preparedness meets opportunity. At the time, there was lots of opportunity for planning and management advisory services in healthcare.

One of Food Systems' most significant innovations in healthcare foodservices to improve patient and resident meal experiences has been the adoption of multi-style meal services. One size meal service doesn't fit all. Multi-style meal service enables the unique foodservice needs of all patients to be met using a variety of meal service styles most appropriate to their length of stay, age, acuity and food preferences, resulting in better nutrition and higher satisfaction. Imagine the first time that we suggested to hospital planners that we not include a beltline but rather go to decentralized galleys with single-person tray assembly? Imagine our clients agreeing to support this plan? We have worked with some very brave foodservice managers and directors. The North Bay Regional Hospital and Northeast Mental Health Centre is worth a site visit.

In 2003, I made a decision that has changed the direction of my career significantly. Byron Kaczmarek gave me the opportunity to merge my consulting firm with Marek Hospitality Inc. to help grow a new business segment-healthcare retail. I became an equity partner and president of both firms. As an owner and senior executive within Marek Hospitality Inc. and as an advisor to our sister company Dana Hospitality Inc., I have had the opportunity to encourage and support our chefs and managers in preparing fresh, healthy, safe foods every day in over 100 locations in Ontario and British Columbia and most recently in Manitoba. Each March we endorse DC's Nutrition Month and also run monthly promotions that encourage healthy eating at work and support workplace wellness.

Our latest innovation is "frescoServe ${ }^{\mathrm{TM}}$ ", a means of extending the scope of retail healthcare foodservices to add a more affordable "fresh" food sparkle to the patient meal experience. Our concept is work redesign. We propose that all back of house functions be combined with retail, as they are business-related, and that patient foodservices focus on patient meal require- 
ments, diet office, and meal assembly. It is a new approach to healthcare retail management services designed for small and medium sized hospitals, so their efforts can be focused on enhancing patient meal service while we take responsibility for the foodservice business.

\section{Mentor and Partner}

Byron is a true entrepreneur and a very successful businessman. It has been my good fortune to meet him, recognize his skills and develop a wonderful working relationship. Byron's approach from his early beginnings in the business was to make food fresh on site every day using qualified chefs. He hired me as an advisor because he wanted to have a nutrition awareness program built in. We introduced the chefs to Anne Lindsay's cookbooks and they adapted them for use in our cafes. More recently we have provided the DC cookbooks as prizes. Over the years Dana and Marek have been proactive in eliminating trans fatty acids; reducing sodium and purchasing over $90 \%$ of our food from Canadian farmers and growers.

\section{What Opportunities Need Entrepreneurial Minded RDs?}

The top opportunities I see are:

- School lunch. Why can't we have a universal school lunch that parents pay for, or are assisted to pay for? We know from our work in independent schools that if everyone in the school participates, we can provide a high quality, freshly prepared meal and snack for under $\$ 6$ a day. We don't want the American system; there has to be a made in Canada solution that would achieve so many other benefits, including supporting our local producers and ensuring that all of our children are well nourished and learn good eating habits.

- Zoomers. The emerging baby boomer cohort finally have the time, money and focus to make their health last. How can we help them? There are many business and work opportunities associated with meeting the needs for information, creative learning and lifestyle change management. There is ecotravel; why not healthy lifestyles travel?

- Restaurants. No more than $15 \%$ of meals served in restaurants would be regarded as healthy eating. What is it going to take to change that? We need more RDs running restaurants. In 1923, Lady Eaton asked Violet Riley to plan and manage the Georgian Room at the new Eatons store on College Street in Toronto. She worked there for 26 years before retiring in 1949. The Georgian Room was regarded as one of the finest dining rooms in Canada, not only for the décor, linens and china, but also for the high quality menu and overall superb management. Kathleen Jeffs worked at the store in Montreal for 23 years. Eatons continued to have dietitians on staff until well into the 1990s. The restaurant business is very different now, but with consumers' heightened interest in healthy eating, glutenfree menus, and lower fat, sodium and calorie options, there are great opportunities for employment and also ownership.
-Applications. There are apps for almost anything. The trick is to develop one that meets a broadly based need, creating high volume use so that advertisers will pay to access your users. In a recent survey of 120,000 students in the U.S.A., Aramark found that $66 \%$ review nutrition labels to select their meals and 50\% check for nutrition information online (1). There is an opportunity to put that nutrient information into a lifestyle knowledge context for them. Interestingly, many young professionals don't cook much but they grow their own herbs and are very interested in the medicinal properties of many exotic ingredients and seasonings. We should be able to build on that interest and monetize it.

- Healthcare meal services. We can't give up on hospital food, on creating "wow" patient meal experiences. My latest campaign is to try to help managers figure out how to get the hot beverages off the tray and served separately. This is one of the major patient complaints and could go a long way to increasing patient satisfaction. It is a well-established practise in Europe and makes intuitive sense. There is lots of room for product, service and information systems innovations, to improve the experience for patients at less cost. Let's get on to it.

\section{How to Act on the Opportunities}

These are just a few of the many emerging opportunities, so a few cautions. First, do not expect that dietitian jobs will be advertised to address such opportunities.

It is important at some stage in your evolution as a professional to get out of that early box of being a clinical or admin dietitian and start thinking for yourself, your interests, and how you might best put your whole person and whole range of skills to work. Mary Sue Waisman told us last year of her mid-career decision to go to chef's school (2). It is a joy for me to meet RDs who have moved into senior executive roles in healthcare and who tell me that they too started as an RD. It helps enormously not only to have women in these senior roles but also to have professionals with a food and nutrition background. We understand that there is much more to healthcare than the medical model.

Imagine a world where health matters more than healthcare. It will take more entrepreneurs or those with an entrepreneurial mindset to make it happen, because there are so many vested interests in the current healthcare system.

\section{How to Make an Entrepreneurial Approach Work}

1. Relationships matter most

2. Referrals are key

3. You need to earn your reward

4. You have to be confident and you must protect your confidence

\section{Relationships Matter Most}

Who needs what you know or do? Fortunately, with social media it is a lot easier to find that out, but how do you get their 
attention with all the noise? Who do you know who knows them? Networking is key. But you have to do or offer something that is worthy of others' attention. Sheryl Sandberg, COO of Facebook, talks a lot about relationships and the importance of mentors in her book Lean In (3). Students just can't approach anyone and say, "I would like you to be my mentor". Mentors choose who they want to mentor.

\section{Referrals are Key}

My strategic coach Dan Sullivan has four refer-ability habits that will surprise you, but no truer words were ever spoken (4):

- Show up on time

- Do what you say you are going to do

- Finish what you start

- Say please and thank you

Very few people have these habits; those who do stand out. They are very successful entrepreneurs. If you want people to remember you and refer you to others, you must develop these habits.

\section{You Need to Earn Your Reward}

If someone said to you, "I want you to do this. It may take you some time, but if you do it and achieve the results I am looking for, I will reward you." Would you do it? Would you risk your time and talent? Some of the largest fortunes have been made by people who agreed to do it. This is the entrepreneurial mindset at work. It is opposite to the entitlement mindset that asks, "What are you going to give me just for showing up?" Entrepreneurs expect to earn their reward. They expect to risk effort and sometimes investment for an even greater return.

A brief comment about the " $\mathrm{M}$ " word-money. Like profit, it is not a four-letter word. You need to value your services and seek the reward that you have earned. As females and caregivers, we struggle with the idea of making money and lots of it. We need to get over it, to unlearn that it is unladylike to discuss money and go for gold. Earn your reward, then capture your reward. Seek to be compensated for what you are worth.

It is a real challenge to be entrepreneurial within a bureaucracy. Some of our healthcare organizations have become more entrepreneurial but there is a bit of a dilemma within the public sector, because so often when incentives are put in place, they backfire. Jane Jacobs wrote about this in her book Systems of Survival where she talked about the two necessary yet in some cases competing roles of "stewardship of the public wealth, wellbeing and safety" and of the commercial sector or "traders - those who create and build wealth"(5). These two systems are of necessity governed by different rules and to some extent different moral codes, but both are needed for progress and sustainability. We expect stewards to stay within the bright yellow lines (even though we have lots of examples where they did not) but we expect traders/entrepreneurs to be creative and often to redraw the lines. In a civil society we need both to do so honestly. As RDs, we do need some of us to be caregivers and stewards, while some of us must be entrepreneurs. All of us know that health matters most and that good food and nutrition are essential to good health.

\section{Be Confident and Protect your Confidence}

Where does confidence come from? It is part of your belief system. If you think you can, you can. If you don't, you can't. You may have heard the phrase magical thinking. Matthew Hutson proposes this in his book The 7 Laws of Magical Thinking (6). His proposition is that magical thinking gives our lives purpose, a sense of control, connection and meaning. There is no scientific theory to explain where belief comes from. Because we are human we can choose to believe.

You must believe in yourself to be an entrepreneur. You must know that you can do what you need to do to hold up your end of any bargain you make, whether it is with your client, customer or partner. And how do you do this? You start small and with small wins and achievements, you grow your confidence. Sadly some of us allow parents, partners or colleagues to take our confidence away. Happily it can be regained, again with small wins every day.

It is my belief that adopting an entrepreneurial mindset is the way forward to be who you are; to be the best that you can and want to be. When you can create your own opportunities, you never need to be fearful again. Try achieving intended results. As you are successful and gain confidence, just do it! Dare to take a risk; dare to do what you were meant to do...to become who you were meant to be.

\section{Acknowledgements:}

I wish to thank my nominees (Catherine MacKenzie, Marilyn Knox, Dr. Janet Chappell, Peter Rick, and Barbara Jaques), the DC Board of Directors, and the members of Dietitians of Canada for this honour.

\section{References}

1. Aramark Press Release. Smartphone App Connects College Students with Healthy Meal Choices; August 23, 2012 [cited 2013 Jun 26]. Available at: http://www.aramark.com/CampusDishSmartphoneApp.aspx

2. Waisman MS. Stepping out: dare to step forward, step back, or just stand still and breathe. Can J Diet Pract Res. 2012 Fall;73(3):147-50.

3. Sandberg S. Lean In: Women, Work and the Will to Lead. Toronto: Random House of Canada Ltd.; 2013.

4. Sullivan D. How the Best Get Better: The Art and Science of Entrepreneurial Success. Toronto: The Strategic Coach Inc.; 2001.

5. Jacobs J. Systems of Survival: A Dialogue on the Moral Foundations of Commerce and Politics. New York: Random House; 1992.

6. Hutson M. The 7 Laws of Magical Thinking: How Irrational Beliefs Keep Us Happy, Healthy and Sane. New York: Penguin Group (USA) Ltd.; 2012. 